\title{
Effects of tenectomy of the medial head of the deep digital flexor on the hindlimbs of healthy horses
}

\author{
[Efeitos da tenectomia da cabeça medial do tendão flexor digital profundo \\ nos membros posterior de cavalos saudáveis] \\ D. Pizzigatti ${ }^{1}$, L.A. Raffael ${ }^{2}$, C.A. Rodrigues ${ }^{2}$, M.J. Watanabe $^{2}$, \\ A.L.G. Alves ${ }^{2}$, L. Barbosa ${ }^{2}$, C.A. Hussni ${ }^{2}$ \\ ${ }^{1}$ Universidade do Oeste de Santa Catarina - Xanxerê, SC \\ ${ }^{2}$ Universidade Estadual Paulista - Botucatu, SP
}

\begin{abstract}
The tenectomy of the medial head of the deep digital flexor (TMHDDF) is a minimally studied surgery used in cases of dorsal subluxation of the proximal interphalangeal joint of the hindlimb in horses. The TMHDDF was evaluated in six healthy horses by the degree of lameness, perimeter of the surgical site, the angle of the distal articular joints, and the linear and angular measures of the hoof. Thus, TMHDDF of the right hindlimb was performed and the contralateral limb was used as a control. Both, right and left limbs were evaluated before surgery, as well as at 15,30 , and 60 days after surgery aiming to evaluate the effects of the surgical procedure in healthy limbs. Data were compared by analysis of variance regarding days and limbs. Values below the significant level $(\mathrm{P}<0.05)$ were analyzed using the Tukey's test. TMHDDF caused a mild increase of the toe length and the height of lateral heel $(0.2 \mathrm{~cm}$ in both), as well as a decrease of the angle of the proximal interphalangeal joint $\left(2^{\circ}\right)$ when comparing the left hindlimb to the right hindlimb, 30 and 60 days after surgery. Overall, TMHDDF did not cause significant changes in the evaluated variables up to the 60 days of surgery.
\end{abstract}

Keywords: tenectomy, medial digital flexor tendon, pastern joint, arthrogoniometry

\section{RESUMO}

A tenectomia da cabeça medial do flexor digital profundo (TCMFDP) é uma técnica cirúrgica pouco estudada, indicada para equinos com subluxação dorsal da articulação interfalângica proximal do membro pélvico. A TCMFDP foi avaliada em seis equinos hígidos no grau de claudicação; na perimetria da área operada; nos ângulos articulares distais; e nas medidas lineares e angulares de parâmetros dos cascos. Nesse sentido, foi realizada a TCMFDP do membro pélvico direito, permanecendo o esquerdo como controle. Ambos os membros foram avaliados nos momentos pré-operatório $(0)$ e 15, 30 e 60 dias após a cirurgia, sendo objetivo avaliar os efeitos do procedimento cirúrgico em membros hígidos. Para comparação dos dados entre momentos e membros, foi realizada análise de variância. Os valores inferiores ao de significância $(P<0,050)$ foram submetidos ao teste de Tukey. A TCMFDP provocou discreto aumento $(0,2 \mathrm{~cm}$, em ambos) do comprimento de pinça e da altura do talão lateral e redução no ângulo da articulação interfalângica proximal $\left(2^{\circ}\right)$ na comparação com o membro pélvico esquerdo aos 30 e 60 dias após a cirurgia no contralateral. Em geral, a TCMFDP não causou alterações influentes nos aspectos avaliados até 60 dias do experimento.

Palavras-chave: tenectomia, tendão flexor digital medial, articulação da quartela, artrogoniometria

Recebido em 26 de setembro de 2018

Aceito em 15 de abril de 2019

E-mail: dietrich.pizzigatti.dvm@gmail.com 


\section{INTRODUCTION}

Due to the specific risks and complications associated with surgical procedures in horses, continuing research is performed to assess the side effects of orthopedic procedures on joint axes and hoof conformation (Hussni, 1991; Hussni et al., 1996; Nicoletti et al., 2000; Hussni, 2002).

One example of the aforementioned surgical complications is the modification of the podophalangeal axis after proximal and distal tenotomies of the insertion of the accessory ligament of the deep digital flexor tendon (DDFT) (Hussni et al., 2010). Likewise, changes in angles of the metacarpophalangeal, distal interphalangeal, and proximal interphalangeal joints, as well as in the angles and measures of the hooves were described on adult horses after tenotomy of the superficial digital flexor (SDFT), and desmotomy of its accessory ligament (Hussni, 2002; Hussni et al., 2010).

The tenectomy of the medial head ( $m$. flexor digitorum [digitalis] medialis) of the DDFT (Mm. flexor digitorum [digitalis] profundi) or medial digital flexor (flexor hallucis longus) is used in cases of dorsal subluxation of the proximal interphalangeal joint (DS-PIJ) of the hindlimb in horses (Adams et al., 1995; Auer, 1999; Ruggles, 2003; Nicoletti et al., 2006; Stashak, 2006). The surgery is performed on the medial aspect of the proximal third of the metatarsal bone III, between the DDFT and the suspensory ligament, by removing a tendon segment of approximately three centimeters (Adams et al., 1995; Auer, 1999; Ruggles, 2003; Nicoletti et al., 2006; Stashak, 2006; Pizzigatti et al., 2013).

This surgical procedure has been used to reduce the PIJ angle through elongation of the DDFT (Pizzigatti et al., 2013) and was first described by Shiroma et al. (1989), after having success in three cases of bilateral DS-PIJ. Prognosis is good, and positive results are expected within seven days after surgery. Good long-term outcomes after this surgery have been recorded up to 10 months (Shiroma et al., 1989; Ruggles, 2003; Nicoletti et al., 2006; Stashak, 2006).

No studies have been carried out evaluating joint angles and hoof conformation after TMHDDF in horses. The objective of this study was to evaluate the influence of the TMHDDF in the locomotion and metatarsophalangeal and interphalangeal joint angles, as well as in the linear and angular measurements of the hoofs in the hindlimb of sound horses.

\section{MATERIALS AND METHODS}

Six sound horses were selected by physical and imaging (radiographic and ultrasonographic) exams. Horse's hooves were trimmed and balanced by a clinician ten days before surgery. The Committee of Ethics and Animal Welfare of the School of Veterinary Medicine and Animal Science, São Paulo State University (UNESP), Botucatu/SP - Brazil, approved the research under protocol number 119/2009. Ten days after trimming, measures and angles of the hoofs, baseline perimeter of the intended region for surgery, and radiographs of both hindlimb were done. Then, the TMHDDF was performed on the right hindlimb (RHL); the left hindlimb (LHL), was considered as the control limb.

The angle formed by the intersection of two lines drawn along the dorsal and sole margin $(\alpha \mathrm{T})$ of both hindlimbs was measured using a goniometer (Hoof protractor, USA). Then, medial and lateral photographs (Sony Cyber-shot ${ }^{\circledR}$ 7,2 Megapixels, USA) of the digits were acquired in order to measure the lateral $(\alpha \mathrm{LH})$ and medial $(\alpha \mathrm{MH})$ angles of the heels using an angular dimension tool (software Corel Draw v.12, Canada) (Figure 1a.) A metric tape was used to obtain the dorsal toe length (T) and height of the medial (hMH) and lateral (hLH) heels, from the weight bearing surface to the coronary band. The frog length was gathered from its base to the apex (Lf) and the width (Wf) from side to side of the bulbs. The length (Lh) and width (Wh) of the hooves were obtained from the toe to the heels and from the medial to the lateral quarters (Figures $1 \mathrm{~b}$ and 1c). 


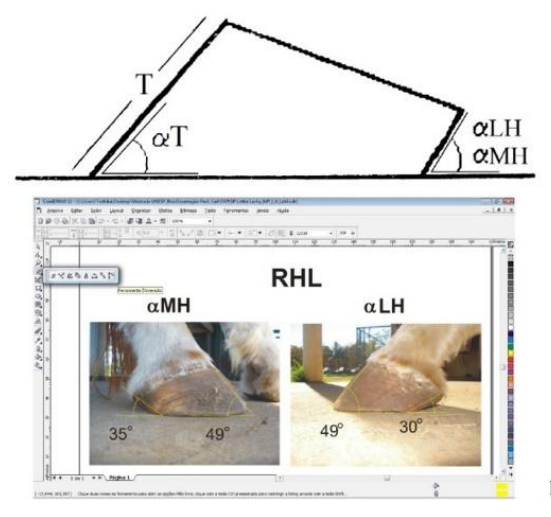

(a)

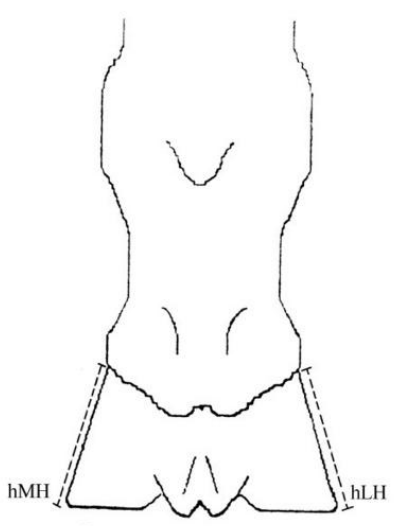

(b)

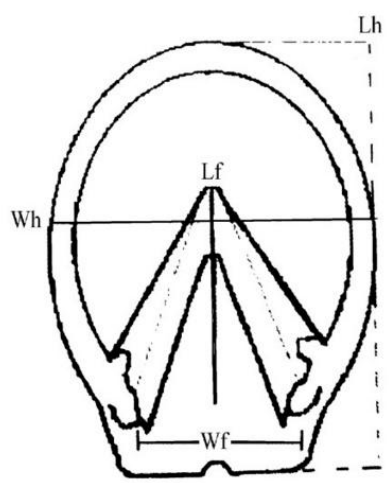

(c)

Figure 1. Measurement of hoof parameters in both hindlimbs: (a) Measure of the dorsal length of toe (T), toe angle $(\alpha \mathrm{T})$, and medial $(\alpha \mathrm{MH})$ and lateral $(\alpha \mathrm{LH})$ heel angles using the angular dimension tool ("Ferramenta Dimensão") of the software Corel Draw 12; (b) Measure of height of the medial (hMH) and lateral (hLH) heels; (c), Measure of length (Lf) and width (Wf) of the frog and length (Lh) and width (Wh) of the hooves.

Each horse stood on a wooden platform to maintain normal weight balance and joint angles. Then, lateromedial radiographs from the diaphysis of the third metatarsal bone to the third phalanx were acquired using a portable X-ray machine (FNX-CTI 90 Plus, Brazil), $30 \mathrm{~cm} \mathrm{x}$ $40 \mathrm{~cm}$ screen size film (Kodak ${ }^{\circledR}$, Brazil) and an automatic film processor (Macrotec NDT MX2 Processor, Brazil).

Radiographs were digitally photographed and identified by animal, limb and day. The angles of the metatarsophalangeal (MPJ), proximal interphalangeal (PIJ) and distal interphalangeal (DIJ) joints were measured by calculating the intersection angle of the lines traced through the diaphyseal axis of the third metatarsal, and proximal and mid phalangeal bones using the angular dimension tool of Corel Draw v.12. At the distal phalanx, the line was drawn along the dorsal face (Figure 2).

The measurement of perimeter of the surgery area was made using a measuring tape (in centimeters) in the proximal metatarsal segment, $1 \mathrm{~cm}$ distal of the chestnut, in both limbs measured. Soreness was subjectively assessed by the response to manual pressure across the surgical area and was categorized as absent, light, mild and severe.

The lameness was evaluated by 2 clinicians with notable experience in locomotor exams.
Clinicians graded the lameness, when present, with the AAEP lameness scale (Lameness..., 2005) by watching the horses walk and trot in a straight line.

For the TMHDDF of the RHL, the horses were pre medicated with intravenous xylazine hydrocloride (Sedazine ${ }^{\circledR}$, Fort Dodge LTDA, Brazil), induced with diazepam (Diazepam União $^{\circledR}$, União química, Brazil) and ketamine hydrochloride (Dopalen ${ }^{\circledR}$, Vetbrands, Brazil) in guaifenesin solution (Éter Gliceril Guaiacol ${ }^{\circledR}$, E.H.G Agrofarma, Brazil) and anesthetized with isoflurane (Isoforine ${ }^{\circledR}$, Cristália Produtos Químicos Farmacêuticos Ltda, Brazil). The animal was restrained in right lateral recumbency. Clipping and surgical scrubbing of the proximal medial surface of the right metatarsus was performed according to the technique described by Nicoletti et al. (2006), starting at the chestnut, a seven-centimeter incision between the deep digital flexor tendon and the second metatarsal bone was made. Subcutaneous tissue and fascia were transected and the medial head of DDF was exposed. A five-centimeter segment of the MDF was resected by sharp incision followed by closing the fascia with a simple continuous pattern using 2-0 polyglactin 910 suture $\left(\mathrm{Vicril}^{\circledR}\right.$ Ethicon, Johnsons \& Johnsons, Brazil.). The skin was closed using a simple interrupted pattern with 2 0 nylon suture (JP ${ }^{\circledR}$, Brazil). 


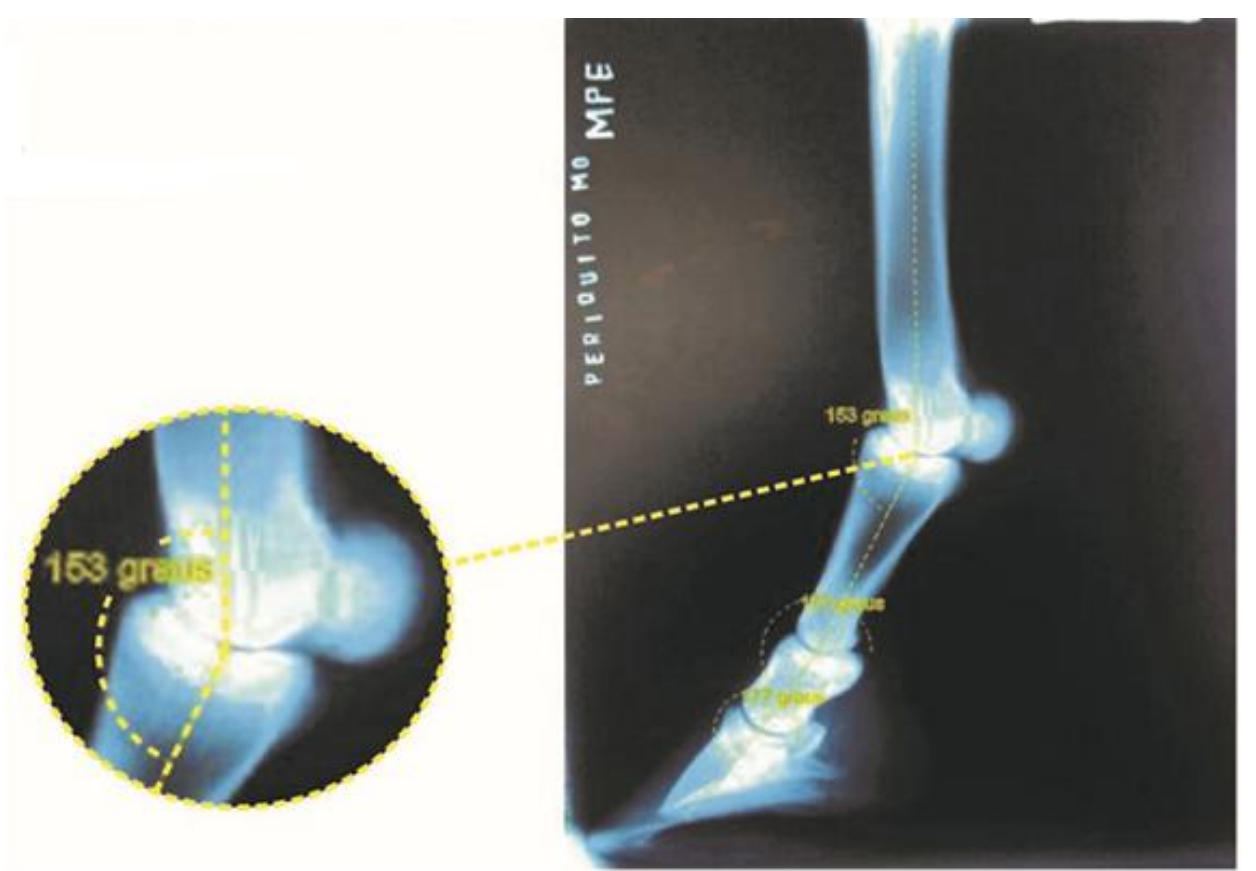

Figure 2. Model of arthrogoniometry control exam before (D0) the surgical procedure in the equine metatarsophalangeal, proximal and distal interphalangeal joints applying the dimension tool ("Ferramenta de Dimensão") of the software Corel Draw 12.

Benzathine penicillin was administered $(20,000$ IU/kg IM - Penfort ${ }^{\circledR}$, Fort Dodge Ltda, Brazil) in anesthesia recovery and then 72 and 144 hours later. Phenylbutazone $(4 \mathrm{mg} / \mathrm{kg}$, IV, BID for five days - Equipalazone ${ }^{\circledR}$, Marcolab, Brazil) was also administered. The horses were kept in stalls and bandage changes were performed daily for 12 days. Then, skin sutures were removed and the animals were released into paddocks. Temperature, heart and respiratory rates and capillary refill time and lameness were assessed daily.

The variables were assessed in both hind limbs before surgery (D0), and at 15 (D15), 30 (D30), and 60 (D60) days after surgery. Joint angles and other hoof variables taken from control and operated limbs were submitted to a blind statistical analysis (ANOVA) at a 5\% level of significance. We compared differences between limbs at each day, then days for each limb and interaction between limbs and days (CallegariJacques, 2003; Santos and Gheyi, 2003). Results under level of significance $5 \%(\mathrm{P}<0.05)$ were submitted to the comparative analysis by the Tukey test.

\section{RESULTS AND DISCUSSION}

Studies in horses have suggested that TMHDDF provides a quick response (at seven days) in ameliorating clinical signs related to subluxation of the PIJ and a short-term (least 30 days) (Shiroma et al., 1989; Auer, 1999; Ruggles, 2003; Nicoletti et al., 2006). In the experimental animals, painful sensibility was observed up to the $10^{\text {th }}$ day, edema up to the $15^{\text {th }}$ day (D15) and the surgical scar was visible up to the $30^{\text {th }}$ day (D30). The media of the surgical perimeter area initially (D0) was $22.3 \pm 1.03 \mathrm{~cm}$, at D15 was $23.5 \pm 0.84 \mathrm{~cm}$ and up to D60 $(22.7 \pm 1.03 \mathrm{~cm})$, was continuous regression of the perimeter, presenting only a discrete difference $(0.6 \mathrm{~cm})$ with the control hindlimb $(22.2 \pm 0.98 \mathrm{~cm})$ at the end of experiment. The pilose coverage of the incision area occurred in all animals up to D60. The clinical parameters evaluated were normal in all animals throughout the experiment.

This aesthetic finding is due to the postoperative inflammatory process with evolution and fibrosis of the fascia incised to access the medial head of the DDFT. The suture of the crural fascia with 20 polyglactin 910 , although better indicated, may have influenced the finding of increase in the 
perimetric area, because according to the literature, this is absorbed by hydrolysis in 40 to 90 days (Thomassian, 2005; Auer and Stick, 2006; Hussni et al., 2010).

The lameness of support RHL grade two (Lameness..., 2005) was observed in most animals at D15, gradually reducing at D30 until D60, where lameness was not observed in most animals (Table 1). Both the lame and regional edema were transient and suggest that they did not interfere in the morphological aspects studied in the hooves and likewise did not interfere in the articular angles after the surgery.

All the mean values of hoof measurements and the distal arthrogoniometric angles are exposed in Table 2.

Table 1. Lameness graduation $(0-5)$ by Aaep (2005), in the of six horses that underwent tenectomy of the medial digital flexor compared at before (D0), 15 (D15), 30 (D30) and 60 (D60) days after the surgical procedure

\begin{tabular}{|c|c|c|c|c|c|c|c|c|}
\hline \multirow{2}{*}{\multicolumn{2}{|c|}{$\begin{array}{l}\text { Days } \\
\text { Limbs }\end{array}$}} & \multicolumn{6}{|c|}{ Animals } & \multirow{4}{*}{$\begin{array}{c}\text { Mean/ } \\
\text { Standard deviation } \\
0 \pm 0\end{array}$} \\
\hline & & \multirow{3}{*}{$\begin{array}{l}\text { I } \\
0 \\
0\end{array}$} & \multirow{2}{*}{$\frac{\text { II }}{0}$} & \multirow{2}{*}{$\begin{array}{c}\text { III } \\
0\end{array}$} & \multirow{2}{*}{$\begin{array}{c}\text { IV } \\
0\end{array}$} & \multirow{2}{*}{$\begin{array}{l}\mathrm{V} \\
0\end{array}$} & \multirow{2}{*}{$\frac{\mathrm{VI}}{0}$} & \\
\hline & LHL & & & & & & & \\
\hline D0 & RHL & & 0 & 0 & 0 & 0 & 0 & \\
\hline \multirow{2}{*}{ D15 } & LHL & 0 & 0 & 0 & 0 & 0 & 0 & $*$ \\
\hline & RHL & 2 & 2 & 1 & 3 & 2 & 2 & $2 \pm 0.63$ \\
\hline \multirow{2}{*}{ D30 } & LHL & 0 & 0 & 0 & 0 & 0 & 0 & $*$ \\
\hline & RHL & 2 & 1 & 1 & 2 & 0 & 1 & $1.17 \pm 0.75$ \\
\hline \multirow{2}{*}{ D60 } & LHL & 0 & 0 & 0 & 0 & 0 & 0 & $*$ \\
\hline & RHL & 0 & 0 & 0 & 1 & 0 & 0 & $0.17 \pm 0.41$ \\
\hline
\end{tabular}

*: Limbs without lameness.

Table 2. Mean $(\bar{x}$, in centimeters) of hoof parameters - dorsal length of toe $(T)$, toe angle $(\alpha T)$, and medial $(\alpha \mathrm{MH})$ and lateral $(\alpha \mathrm{LH})$ heel angles, height of the medial $(\mathrm{hMH})$ and lateral $(\mathrm{hLH})$ heels, length (Lf) and width (Wf) of the frog and length (Lh) and width (Wh) of the hooves; and angles (in degrees) of the metatarsophalangeal (MPJ), proximal interphalangeal (PIJ) and distal interphalangeal (DIJ) joint in left (LHL) and right - operated (RHL) hind limbs of six horses that underwent tenectomy of the medial digital flexor compared at before (D0), 15 (D15), 30 (D30) and 60 (D60) days after the surgical procedure

\begin{tabular}{|c|c|c|c|c|c|c|c|c|c|c|c|c|c|c|}
\hline \multirow[t]{2}{*}{ Days } & \multirow{2}{*}{ Limbs } & \multicolumn{10}{|c|}{ Hoof Parameters } & \multicolumn{3}{|c|}{ Articular Angles } \\
\hline & & $\mathrm{T}^{*}$ & $\alpha \mathrm{T}$ & $\alpha \mathrm{LH}$ & $\alpha \mathrm{MH}$ & $\mathrm{hMH}$ & hLH* & $\mathrm{Wf}$ & Lf & $\mathrm{Wh}$ & $\mathrm{Lh}$ & MPJ & PIJ* & DIJ \\
\hline \multirow{2}{*}{ D } & LHL & $\begin{array}{l}\bar{x} \alpha \\
79 \mathrm{aA}\end{array}$ & $\begin{array}{c}\bar{x} \alpha \\
48.0 \mathrm{aA}\end{array}$ & $\begin{array}{c}\bar{x} \alpha \\
37.8 \mathrm{aAA}\end{array}$ & $\begin{array}{c}\bar{x} \alpha \\
39.2 \mathrm{aA}\end{array}$ & $\begin{array}{c}\bar{x} \alpha \\
3.8 \mathrm{aA}\end{array}$ & $\begin{array}{r}\bar{x} \alpha \\
3.7 \mathrm{aA}\end{array}$ & $\begin{array}{c}\bar{x} \alpha \\
5.5 \mathrm{aA}\end{array}$ & $\begin{array}{c}\bar{x} \alpha \\
7.7 \mathrm{aA}\end{array}$ & $\begin{array}{c}\bar{x} \alpha \\
11.1 \mathrm{aA}\end{array}$ & $\begin{array}{c}\bar{x} \mathrm{~A} \\
11.8 \mathrm{aA}\end{array}$ & $\begin{array}{c}\bar{x} \alpha \\
157.2 \mathrm{aA}\end{array}$ & $\begin{array}{c}\bar{x} \alpha \\
173.0 \mathrm{aA}\end{array}$ & $\begin{array}{c}\bar{x} \alpha \\
172.5 \mathrm{aA}\end{array}$ \\
\hline & RHL & $7.9 \mathrm{aB}$ & $49.2 \mathrm{aA}$ & $37.0 \mathrm{aA}$ & $36.5 \mathrm{aA}$ & $3.9 \mathrm{aA}$ & $4.0 \mathrm{aA}$ & $5.2 \mathrm{aA}$ & 7.9aA & $11.0 \mathrm{aA}$ & $12.2 \mathrm{aA}$ & $159.0 \mathrm{aA}$ & $172.5 \mathrm{aA}$ & $170.3 \mathrm{aA}$ \\
\hline \multirow{2}{*}{ D15 } & LHL & 7.8abA & $48.3 \mathrm{aA}$ & $38.8 \mathrm{aA}$ & $38.2 \mathrm{aA}$ & $3.8 \mathrm{aA}$ & $3.8 \mathrm{aA}$ & $5.1 \mathrm{aA}$ & $7.8 \mathrm{aA}$ & $11.0 \mathrm{aA}$ & $11.9 \mathrm{aA}$ & $160.8 \mathrm{aA}$ & $171.0 \mathrm{aA}$ & $171.5 \mathrm{aA}$ \\
\hline & RHL & 7.8abB & $49.7 \mathrm{aA}$ & $40.3 \mathrm{aA}$ & $39.5 \mathrm{aA}$ & $3.8 \mathrm{aA}$ & $3.8 \mathrm{aA}$ & $5.0 \mathrm{aA}$ & $7.8 \mathrm{aA}$ & $11.0 \mathrm{aA}$ & $12.0 \mathrm{aA}$ & $160.3 \mathrm{aA}$ & $171.5 \mathrm{aA}$ & $169.8 \mathrm{aA}$ \\
\hline \multirow{2}{*}{ D30 } & LHL & 8.0abA & $48.5 \mathrm{aA}$ & $36.8 \mathrm{aA}$ & $37.5 \mathrm{aA}$ & $3.8 \mathrm{aA}$ & $4.0 \mathrm{abA}$ & $5.3 \mathrm{aA}$ & 7.7aA & $11.2 \mathrm{aA}$ & $11.6 \mathrm{aA}$ & $157.3 \mathrm{aA}$ & $170.7 \mathrm{bA}$ & $169.5 \mathrm{aA}$ \\
\hline & RHL & 8.1abB & $49.0 \mathrm{aA}$ & $37.0 \mathrm{aA}$ & $36.5 \mathrm{aA}$ & $3.9 \mathrm{aA}$ & 4.0abA & $5.1 \mathrm{aA}$ & $7.5 \mathrm{aA}$ & $11.0 \mathrm{aA}$ & $11.7 \mathrm{aA}$ & $157.0 \mathrm{aA}$ & $170.0 \mathrm{bA}$ & $172.3 \mathrm{aA}$ \\
\hline \multirow{2}{*}{ D60 } & LHL & $8.0 \mathrm{bA}$ & $48.3 \mathrm{aA}$ & $37.7 \mathrm{aA}$ & $39.0 \mathrm{aA}$ & $4.5 \mathrm{aA}$ & $4.7 \mathrm{bA}$ & $5.3 \mathrm{aA}$ & 7.6aA & $11.2 \mathrm{aA}$ & $12.0 \mathrm{aA}$ & $158.7 \mathrm{aA}$ & $170.0 \mathrm{bA}$ & $174.0 \mathrm{aA}$ \\
\hline & RHL & $8.2 \mathrm{bB}$ & $48.7 \mathrm{aA}$ & $39.0 \mathrm{aA}$ & $37.2 \mathrm{aA}$ & $4.4 \mathrm{aA}$ & $4.5 \mathrm{bA}$ & $5.3 \mathrm{aA}$ & $7.8 \mathrm{aA}$ & $11.1 \mathrm{aA}$ & $12.0 \mathrm{aA}$ & $159.7 \mathrm{aA}$ & $170.8 \mathrm{bA}$ & $172.5 \mathrm{aA}$ \\
\hline
\end{tabular}

*: Variables with significant differences $(\mathrm{P}<0.05)$

$\alpha$ : For each limb, averages of the days followed by at least one same letter does not differ significantly $(\mathrm{P}<0.05)$.

Different lower case letters indicate significant differences between days $(\mathrm{P}<0.05)$.

Different capital letters indicate differences between the limbs $(\mathrm{P}<0.05)$.

From all hooves parameters evaluated only the toe length (T) and height of lateral heel (hLH) had significative difference. Values of $\mathrm{T}$ are presented in Table 2. Significant differences were found between days $(\mathrm{P}=0.047)$ and limb $(\mathrm{P}=0.036)$. Tukey's test pointed out differences between D0 and D60 $(\mathrm{P}=0.008)$, and between left and right limbs $(\mathrm{P}=0.037)$. A difference of
$0.2 \mathrm{~cm}$ in the overall mean values of the $\mathrm{T}$ found when compared the operated and the control limb. This variation is likely due to decreased tension of the DDFT or wearing difference caused by natural resting of the operated limb. Thus, the trendline for the operated limb suggests a sustained overgrowing of $\mathrm{T}$ in the operated limb when compared with the control. 
The mean of the $\mathrm{T}$ found in our study do not correspond to the general mean $(8.6$ to $8.67 \mathrm{~cm})$ found by Nicoletti et al. (2000). However, compared to wild horses studied by Ovnicek et al. (1995), the value of $\mathrm{T}$ is similar (6.35 to $8.25 \mathrm{~cm})$, suggesting that this parameter also underwent terrain influences on wear of the $\mathrm{T}$.

The values of $\alpha \mathrm{T}$ were lower than those in literature (i.e., 52.7 to 52.9) in the pelvic limbs (Nicoletti et al., 2000). The same authors stated measures of 32.6 to 33.4 for the $\alpha \mathrm{LH}$, and 33.1 to 33.4 for the $\alpha \mathrm{MH}$ for the hind limbs. In our study, all horses (6 animals) had differences higher than $5 \%$ when compared the values of the $\alpha \mathrm{T}$ between the days, which characterizes a tubular asymmetry of toe-heel (Nicoletti et al., 2000). This allowed the toe to grow following a concave pattern, which caused dorsoplantar imbalance, without affecting the distal interphalangeal axis but the proximal interphalangeal angle instead. The solar margin of the third phalanx was not parallel to the weight bearing surface of the hoof, which might lead to a decrease in the height of the heel (Turner, 1992; Stashak, 2006).

Differences between the mean values of the height of the heel are presented in Table 2 . Analysis of variance showed significant differences between days $(\mathrm{P}=0.024)$. The Tukey test indicated significant differences between days D0 x D60 $(\mathrm{P}=0.039)$; and D15 x D60 $(\mathrm{P}=$ $0.034)$. Values of hLH and hHM ranged from 3.7 to 4.7 and 3.8 to $4.5 \mathrm{~cm}$ for the LHL; and from 3.8 to 4.4 and 4.1 to $4.4 \mathrm{~cm}$, for the RHL, respectively. The height of the heels mildly increased during the period of observation in both hind limbs, showing mean values higher than in literature (i.e., 3.63 and $3.66 \mathrm{~cm}$, respectively), when in natural wear (Nicoletti et al., 2000). However, mean values from the present study were similar to other studies which assessed the height of the heels (i.e., from 3.8 to $4.6 \mathrm{~cm})$ in tenectomy of the SDFT or desmotomy in the superior check ligament (Hussni, 2002). In the present study, elevations of the heels were similar in both limbs, and horses presented no lateromedial imbalance, which are animals that have differences up to $0.5 \mathrm{~cm}$ in the height of the heels (Turner, 1992; Nicoletti et al., 2000). The comparative analysis of the moments shows that after the D15, the hull growth response was discretely significant, but not related to the procedure used but to the recovery time where the animals remained in paddok until the $14^{\text {th }}$ day, and were then released in picket.

Width (Wf) and (Lf) length of frog variables not presenting statistical significance and then media values were between 5.1 to 5.5 and 7.6 to $7.8 \mathrm{~cm}$ for LHL; and 5.0 to 5.3 and 7.5 to $7.9 \mathrm{~cm}$ for the RHL, respectively. The values of frog length and width by Nicoletti et al. (2000) (i.e., 7.7 to $7.72 \mathrm{~cm}$ for $\mathrm{Lf}$; and 5.85 to $5.84 \mathrm{~cm}$ for $\mathrm{Wf}$ ) were higher than in the present study. Using techniques for identifying atrophy of the frog or club feet, no horse had frog width values smaller than $67 \%$ or $2 / 3$ of its length (Turner, 1992; Stashak, 2006).

The width (Wh) and length (Lh) of the hoof variables don't have statistical significance and the media values were between 11 to $11.2 \mathrm{~cm}$ and 11.6 to $12.0 \mathrm{~cm}$ for LHL; and between 11 to 11.1 and 11.7 to $12.2 \mathrm{~cm}$ for the RHL, respectively. Comparing with media values of the $\mathrm{Wh}$ and $\mathrm{Lh}$ observed for Nicoletti et al. (2000) and Parés et al. (2012), both were similar (11.12 to $11.08 \mathrm{~cm}$ for Wh and 12.78 to $12.82 \mathrm{~cm}$ for $\mathrm{Lh}$ ).

Plotting the angles of the articular axes of the digit is a simple method, already well established by other authors (Emery et al., 1977; Bushe et al., 1987; Shoemaker et al., 1991; Hussni et al., 1996; Alexander et al., 2001; Hussni et al., 2010). In this work, we modified the computational analysis of non-cartographic photogrammetry of the radiographs for the measurement of arthrogoniometry - angles of the articular axes. The digitalization and computational analysis of the images allowed to trace the diaphyseal axes. Previous studies that refer to the angular conformation of the pelvic digits for horses do so in an imprecise manner (Kolb, 1984). In this work, the values were validated with studies that similarly evaluated the thoracic limbs (Bushe et al., 1987; Shoemaker et al., 1991; Nicoletti et al., 2000; Alexander et al., 2001; Hussni et al., 2010).

Among the joint variables studied, no significant differences were observed in the statistical analyzes concerning the MPJ and DIJ, only in relation to PIJ. The mean values of the angles of the MPJ in our study varied between 157.2 to 160.8 for the LHL and 157 to 160.3 for RHL. Comparing the evaluation of thoracic limbs 
presented in the literature, it was among the average described from other studies. They were from 144 to 150 in Shoemaker et al. (1991); and, from 144 to 148.2 in Cabral et al. (2004). In the study by Bushe et al. (1987), the mean angle of the MPJ using radiographs was 154.2 .

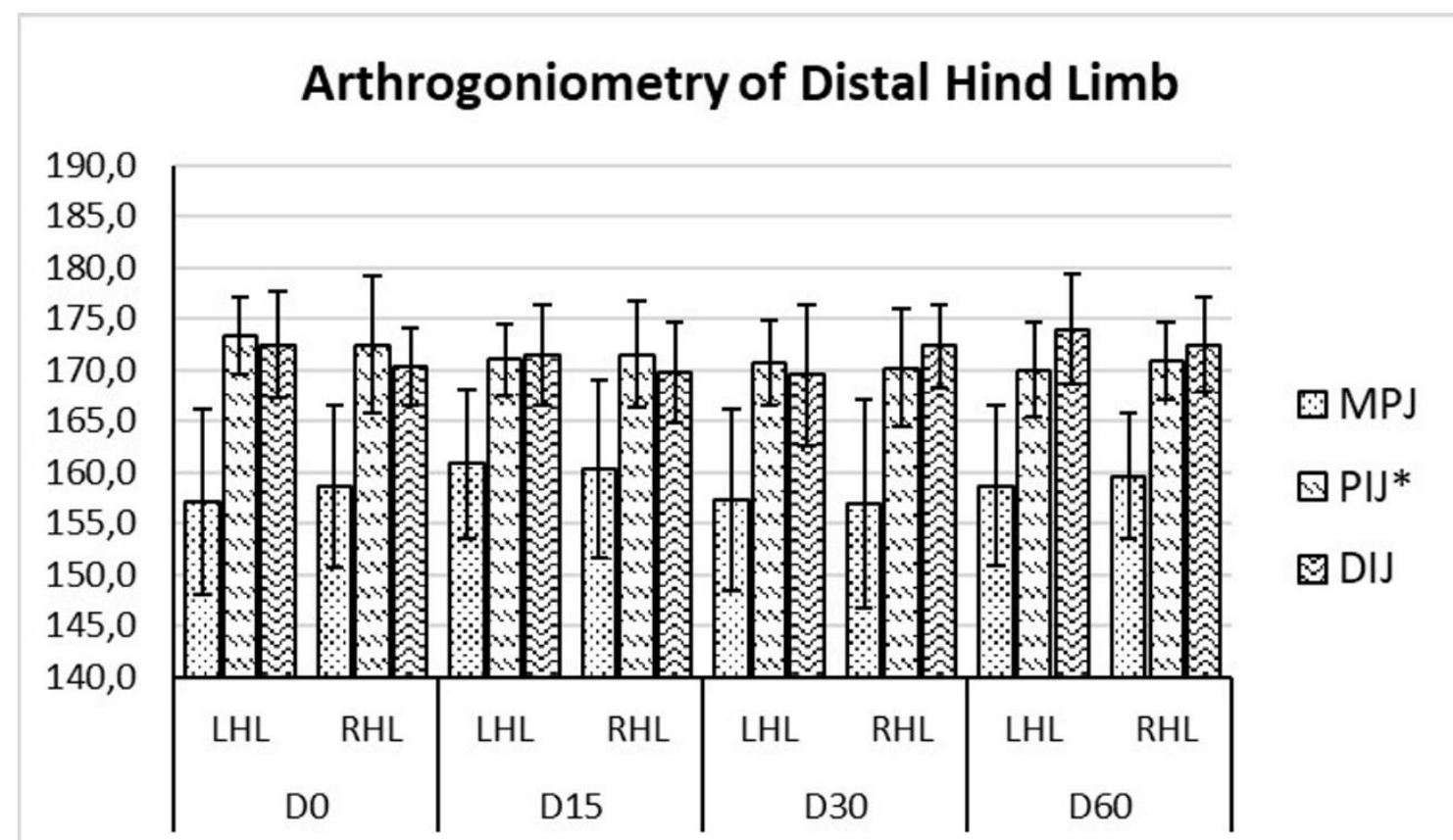

Figure 3. Representation of the means and standard deviations of the angles of the metatarsophalangeal (MPJ), proximal (PIJ) and distal interphalangeal joint (DIJ) in left (LHL) and right - operated (RHL) hind limbs of six horses that underwent tenectomy of the medial digital flexor compared at before (D0), 15 (D15), 30 (D30) and 60 (D60) days after the surgical procedure. *: Variables with significant differences $(\mathrm{P}<0.05)$.

The difference in the mean values of AIP of both hind limbs are presented in Table 2 and Figure 3. Analysis of variance showed significant differences between days $(\mathrm{P}=0.023)$ and in the comparative analysis indicated a difference between days D0 x D30 $(\mathrm{P}=0.033)$ and D0 $\mathrm{x}$ M60 $(\mathrm{P}=0.033)$. The mean values of PIJ varied between 173 at 170 for the LHL and 172.5 at 170 for the RHL. We found similar angles in the PIJ of the hind limbs as Bushe et al. (1987) in the PIJ (i.e., 166 to 173.3 for the forelimbs). This same researcher also refuted the idea that this joint would be aligned with the DIJ and identified a correlation coefficient of $1: 0.31$. This demonstrates that the angle of the hoof imposes changes over the axis of the PIJ that are even greater than those changes observed at the DIJ (1 : $0.91^{\circ}$ ). Nevertheless, data in the present study did not show that relation. Our data shows a diminution of up to 2 of the PIJ and DIJ angles, without influencing the angle of the toe of the operated limbs. It was hypothesized that the angle of the PIJ would be reduced due to the decreased tensional forces after tenectomy of the medial digital flexor (Shiroma et al., 1989; Nicoletti et al., 2000) This reduction in the angle of the PIJ was observed in our study. However, the angle of the PIJ of the non-operated limb varied in the same degree, which may be explained by the overload caused by the defective weight bearing of the operated limb.

\section{CONCLUSION}

The overall analysis of the hoof-related parameters and the joint angles showed that tenectomy of the medial digital flexor influenced the conformation of the PIJ and wear of the hooves. Our findings suggest that this surgical procedure causes a slight decrease in the tensional forces of the deep flexor group, leading to higher extensibility of the PIJ. In addition to the angle modification, one might suspect that there was diminution of the cranial phase of the 
gait and so a higher pressure over the two last thirds of the hooves, causing less wear of the toe and symmetric wear of the medial and lateral heels. However, studies of biomechanical gait in this case should be done to prove this finding.

\section{ACKNOWLEDGEMENT}

The authors wish to express their sincere thanks and gratitude to State of São Paulo Research Support Foundation (FAPESP-Fundação de Amparo à Pesquisa do Estado de São Paulo, in Brazil), for the financial support, by granting the first author a scholarship during her Master's course and research financial aid (Process $n$ 2009/12159-9).

\section{REFERÊNCIAS}

ADAMS, P.; HONNAS, C.M.; FORD, T.S.; WATKINS, J.P. Arthrodesis of a subluxated proximal interphalangeal joint in a horse. Equine Pract., v.17, p.26-31, 1995.

ALEXANDER, G.R.; GIBSON, K.T.; DAY, R.E.; ROBERTSON, I.D. Effects of superior check desmotomy on flexor tendon and suspensory ligament strain in equine cadaver limbs. Vet. Surg., v.30, p.522-527, 2001.

AUER, J.A. Disease of pastern region. In: COLAHAN, P.T.; MAYHEW, I.G. et al. (Eds.). Equine medicine and surgery. Missouri: Mosby, 1999. p.1548-1550.

AUER, J.A.; STICK, J.A. Equine surgery. Missouri: Saunders Elsevier, 2006. 1455p.

BUSHE, T.; TURNER, T.A.; POULOS, P.W.; HARWELL, N.M. The effect of hoof angle on coffin, pastern and fetlock joint angles. In: ANNUAL CONVENTION OF AMERICAN ASSOCIATION OF EQUINE PRACTITIONERS, 33., 1987, New Orleans. Proceedings... New Orleans: AAEP. p.729-738.

CABRAL, G.C.; ALMEIDA, F.Q.; AZEVEDO, P.C.N. et al. Avaliação morfométrica de eqüinos da raça Mangalarga Marchador: medidas angulares. Rev. Bras. Zootec., v.33, p.1790-1797, 2004.

CALLEGARI-JACQUES, S.M. (Eds.). Bioestatística: princípios e aplicações. Porto Alegre: Artmed, 2003. 255p.
EMERY, L.; MILLER, J.; VAN HOOSEN, N. (Eds.). Horseshoeing theory and hoof care. Philadelphia: Lea \& Febiger, 1977, 283p.

HUSSNI, C.A. Tenotomia do músculo flexor digital profundo proximal à inserção do ligamento acessório: proposta de uma nova técnica cirúrgica em equinos e seus efeitos sobre os ângulos das articulações metacarpofalangeana e interfalangeana. 1991. 37f Dissertação (Mestrado em Cirurgia de Grandes Animais) Faculdade de Medicina Veterinária e Zootecnia, Universidade Estadual Paulista, Botucatu, SP.

HUSSNI, C.A. Efeitos da tenotomia do tendão flexor digital superficial e da desmotomia do acessório sobre os ângulos articulares e sobre os cascos dos eqüinos. 2002. 49f Tese (Livredocência). Faculdade de Medicina Veterinária e Zootecnia, Universidade Estadual Paulista, Botucatu, SP.

HUSSNI, C.A.; NICOLETTI, J.L.M.; THOMASSIAN, A. et al. Variações dos ângulos das articulações metacarpofalangeanas e interfalângicas frente a duas técnicas de tenotomia do flexor digital profundo em eqüinos. Rev. Med. Vet. Zootec., v.8, p.27-34, 1996.

HUSSNI, C.A.; WATANABE, M.J.; ALVES, A.L.G. et al. Tenotomia do músculo flexor digital superficial e desmotomia acessória em equinos: Goniometria, radiometacarpiana, metacarpofalângica e interfalângica. Cienc. Anim. Bras., v.11, p.218-225, 2010.

KOLB, E. (Ed.). Fisiologia veterinária. Rio de Janeiro: Guanabara, 1984. 612p.

LAMENESS exams: evaluating the lame horse. Lexington: AAEP, 2005. Available in: $<\mathrm{http}$ ///www.aaep.org/health_articles_view.php?i $\mathrm{d}=280>$. Accessed in: 23 Oct. 2017.

NICOLETTI, J.L.M.; ALVES, A.L.G.; HUSSNI, C.A.; THOMASSIAN, A. Tenectomia da cabeça medial do flexor digital profundo em eqüinos. Rev. Med. Vet. Zootec., v. 13, p.169-172, 2006.

NICOLETTI, J.L.M.; SCHLEGEL, C.; THOMASSIAN, A. et al. Mensuração do casco de equinos para identificação objetiva de anormalidade de conformação. Vet. Notícias, v.6, p.61-68, 2000 . 
OVNICEK, G.; ERFLE, J.B.; PETERS, D.F. Wild horse hoof patterns offer a formula for preventing and treating lameness. In: ANNUAL CONVENTION OF THE AMERICAN ASSOCIATION OF EQUINE PRACTITIONERS, 41., 1995, Lexington. Proceedings... Lexington: AAEP, 1995. p.258260.

PARÉS I CASANOVA, P.M.; OOSTERLINCK, M. Hoof size and symmetry in young Catalan pyrenean horses reared under semi-extensive conditions. J. Equine Vet. Sci., v.32, p.231-234, 2012 .

PIZZIGATTI, D.; HUSSNI, C.A.; RODRIGUES, C.A. et al. Bilateral dorsal subluxation of the proximal interphalangeal joint of the hind limb in a mare: case report. J. Equine Vet. Sci., v.33, p.746-750, 2013.

RUGGLES, A.J. The proximal and middle phalanges and proximal interphalangeal joint. In: ROSS, M.W.; DYSON, S.J. (Eds.). Diagnosis and management of lameness in the horse. Missouri: Saunders Elsevier, 2003. p.342-347.

SANTOS, J.W.; GHEYI, H.R. (Eds). Estatística experimental aplicada. Campina Grande: Gráfica Marcone, 2003. 213p.
SHIROMA, J.T.; ENGEL, H.N.; WAGNER, P.C.; WATROUS, B.J. Dorsal subluxation of the proximal interphalangeal joint in the pelvic limb of three horses. J. Am. Vet. Med. Assoc., v.195, p.777-780, 1989.

SHOEMAKER, R.S.; BERTONE, A.L.; MOHAMMAD, L.N.; ARMS, S.W. Desmotomy of the accessory ligament of the superficial digital flexor muscle in equine cadaver limbs. Vet. Surg., v.20, p.245-252, 1991.

STASHAK, T.S. Luxação e subluxação da articulação interfalângica proximal (quartela). In: STASHAK, T.S. (Ed.). Claudicação em eqüinos segundo Adams. São Paulo: Roca, 2006. p.694696.

THOMASSIAN, A. (Ed.). Enfermidades dos cavalos. São Paulo: Varela, 2005. 573p.

TURNER, T.A. The use of hoof measurements for the objective assessment of hoof balance. In: ANNUAL CONVENTION OF THE AMERICAN ASSOCIATION OF EQUINE PRACTITIONERS, 34., 1992, Orlando Proceedings..., Orlando: AAEP, 1992. p.389395. 